\title{
Development Of A Boarding House Search Information System Using The Waterfall Model
}

\author{
Yudha Dwi Putra Negara*, Dwi Rizal Setiawan, Eka Mala Sari Rochman, and Fifin Ayu Mufarroha \\ Informatics Engineering Department, University of Trunojoyo Madura, Indonesia
}

\begin{abstract}
Internet technology can balance entrepreneurs in their efforts to develop their business ventures. Boarding house business. In Indonesia, especially in Madura, educational centers are mushrooming, especially private colleges and universities. This is followed by an increase in the number of houses or special buildings that offer boarding services for students who need them. The purpose of this research is to make a prototype application for finding and ordering boarding houses in Telang to make it easier for boarding house seekers to find information related to boarding houses that match what they want without having to go to the place one by one. As for the boarding house owners help recommend their boarding house. The stages in this study adopt the Waterfall system development method which consists of literature study, problem analysis, requirements modelling, business process modelling, system design and the results of each stage in building a boarding house search system. The results of this study indicate that the test is valid, that is, the compatibility test found minor issues on the IE, Firefox and Safari web browsers, but in this test sampled the opera, chrome and Firefox web browsers, this test is considered valid.
\end{abstract}

Keywords: Prototype Application, Boarding Houses, Waterfall Model

\section{Introduction}

Technology and Communication can make it easier to get the information we need [1][2][3]. One of the containers that we feel most needed in the world of information and communication technology today is the Internet [4][5][6]. Everyone can use the Internet, including entrepreneurs in an effort to develop their business ventures [7][8]. Entrepreneurs must balance their business with these increasingly sophisticated technological advances to get big profits or profits for their companies [9].

Kost is a service that offers a room or place to stay with a certain amount of payment for each certain period (usually monthly payments)[10]. In Indonesia, especially in Madura, educational centers are mushrooming, especially private colleges and universities. This is followed by an increase in the number of houses or special buildings that offer boarding services for students who need them. This service is not free, that is, it involves a certain number of payments for each period, which is usually calculated per month or per semester. The rapid arrival of Trunojoyo Madura University students from outside Bangkalan was not supported by the means to obtain information about boarding service providers. Because the new students of Trunojoyo Madura University who come from outside the city of Bangkalan require a long process of adaptation to get to know the new environment, so it is difficult to find a place to live in the city they have just visited.

Previously, students who were looking for boarding houses had difficulties, namely by looking directly for boarding houses that were still available. During this pandemic, it is recommended to reduce face-to-face activities. This boarding house search system has the potential because it can also save time by using only website-based information system technology to find what you want.

With the above background, the author wants to develop a website-based search information system for boarding houses so that information can be obtained easily and can find out the location and specifications of the boarding house. Therefore, the author took the initiative and was very interested in taking the title about the boarding house system in Telang.

\section{Literature Review}

In a previous study with the title Design of a Point of Sale (POS) Software Information System with the WebBased Waterfall Method. Based on the results of the study, researchers were able to design a point of sale system that had been successfully built and the tests that had been carried out. point of sale system can help administrators and cashiers (entrepreneurs) in managing

\footnotetext{
* Corresponding author : yudha.putra@trunojoyo.ac.id
} 
their business flow [11]. In addition, several researchers have conducted research on the development of information systems using the waterfall methodology [12]-[17][18]. From the results of these studies managed to create a system that has been tested. In another study using the waterfall methodology with system testing using SortSite to test compatibility rather than the system that will be run later. In compatibility testing, SortSite divides 3 categories of problems [19] namely critical issues, major issues and minor issues. From the compatibility test, the results are quite compatible because the system can run on various web browser platforms such as Firefox, chrome, opera mini. Other research makes a tour and travel reservation information system[20]. This system is designed using the Objected Oriented method. Another research makes E-Commerce System Design Using Rapid Application Development Model. From the results of this study, it can increase sales because buyers do not only come from around the store, but also get customers from various regions and even abroad.[21].

\section{Methods}

The method used in the study to achieve the research objectives on the boarding information system in the telang area, among others, is knowing the needs analysis for the boarding house search system in the telang area and knowing the results of the design of the needs analysis that has been set for the boarding information system in the telang area. In this study, the author applies a design based on phases and rules in the Software Development Life Cycle (SDLC) using Waterfall because it is in accordance with the information system modelling stage of the analysis and design section.[22]-[25]. The first stage is the literature study phase by finding sources of literature for the theoretical basis, then problem analysis by interviewing and collecting data using observation and interview methods. The third stage is modelling needs by means of needs analysis based on the results of interviews and data collection. Followed by doing business process modelling. The fifth stage is to design the system by following the rules based on the Software Development Life Cycle using UML. The sixth stage is testing the implementation using sortsite software. The last stage is drawing conclusions based on the formulation of the problem and providing suggestions for future research.

\section{Result}

Based on the stages of the research method used, namely Software Development Life Cycle Waterfall Model. Furthermore, the discussion process of each stage is carried out, namely literature study, problem analysis, needs modelling, business process modelling, system design and the results of each stage in building a boarding house search system.

\subsection{Literature Review}

At the literature study stage, it is necessary to collect several references such as journals, articles, internet and so on related to this research.

\subsection{Problem analysis}

At the problem analysis stage, interviews and observations were made to obtain the data needed during the construction of the boarding house search system. The search system functional requirements resulted in a system that had 3 users, namely Admin, Boarding Owner, and Prospective Tenants. Meanwhile, the functional requirements needed are managing boarding houses, registering boarding house owners, managing boarding house owners, boarding houses, boarding details, rental transactions, tenant registration, and managing tenant data.

\subsection{Requirement Modelling}

Requirement's modelling is described in the form of a use case based on the results of the problem analysis as depicted in the figure 1 .

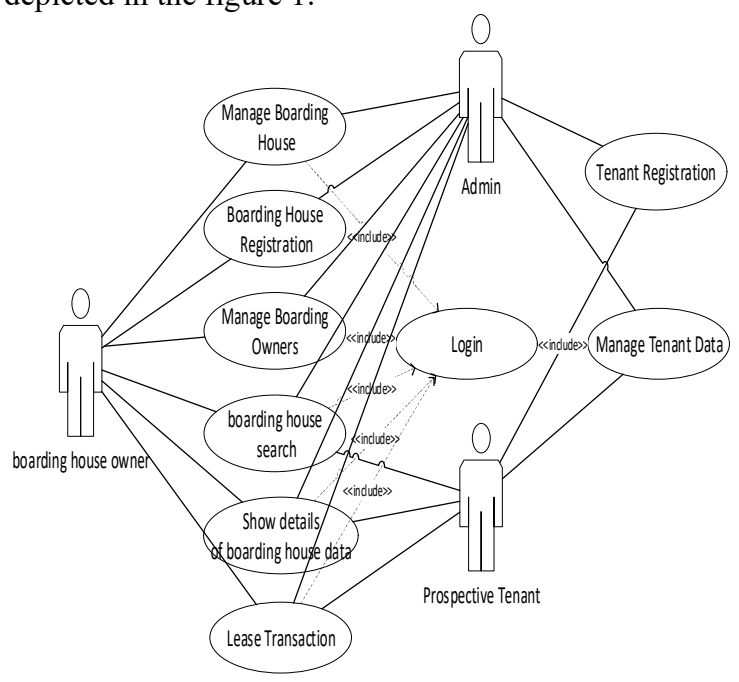

Fig. 1. Use case Diagram.

Use case description, is a description of each use case in the application.

(a) Description of the use case for the owner of the boarding house as well as the admin.

\subsubsection{Description of the use case for the owner of the boarding house as well as the admin.}

1. Login

The use case describes the actor logging in

2. Manage Boarding House

The use case describes the admin or Boarding House owner being able to manage the boarding house

3. Boarding House Registration

The use case describes the boarding house owner registering an account to be able to input boarding room data 
4. Manage Boarding Owners

The use case illustrates that the administrator or boarding house owner can manage the boarding house owner's data. Can manage room data and photos of rooms and facilities.

5. Boarding House Search

The use case illustrates that all users can search for boarding rooms and filter according to user needs.

6. Show details of boarding house data

The use case illustrates that all users can see the boarding room in detail

7. Lease Transaction

Use case describes all users can manage transaction data

8. Tenant Registration

The use case illustrates that the admin user or prospective tenant can register an account so that they can make rental transactions.

9. Manage Tenant Data

The use case illustrates that the admin user or prospective tenant can manage the data of prospective tenants.

\subsection{Business process modelling}

Process modelling is described using BPMN based on the results of the problem analysis as depicted in Figure 2

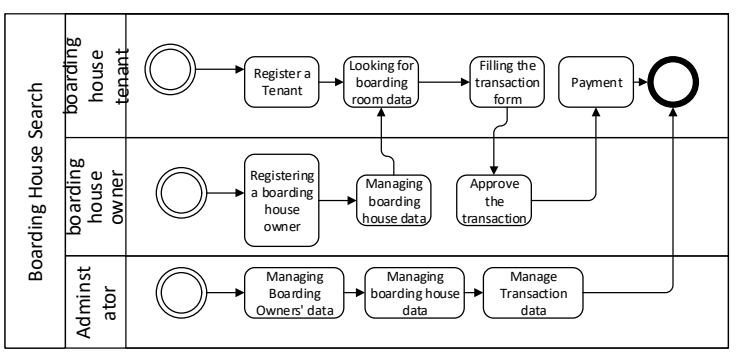

Fig. 2. Business Process Modelling Notation.

The business process carried out with the first stage of the boarding house owner registering an account to be able to input data on the rooms offered so that prospective tenants can choose the room they want. After the rooms match, the prospective tenants make transactions for room rentals. After that, the room owner verified the transaction and then the prospective tenant of the boarding room made payment. After the payment is complete, the prospective boarding house tenant has the right to occupy the room that has been ordered.

\subsection{Design}

At this stage, class diagram design and user interface design are carried out. The results of the class diagram design can be seen in Figure 3.

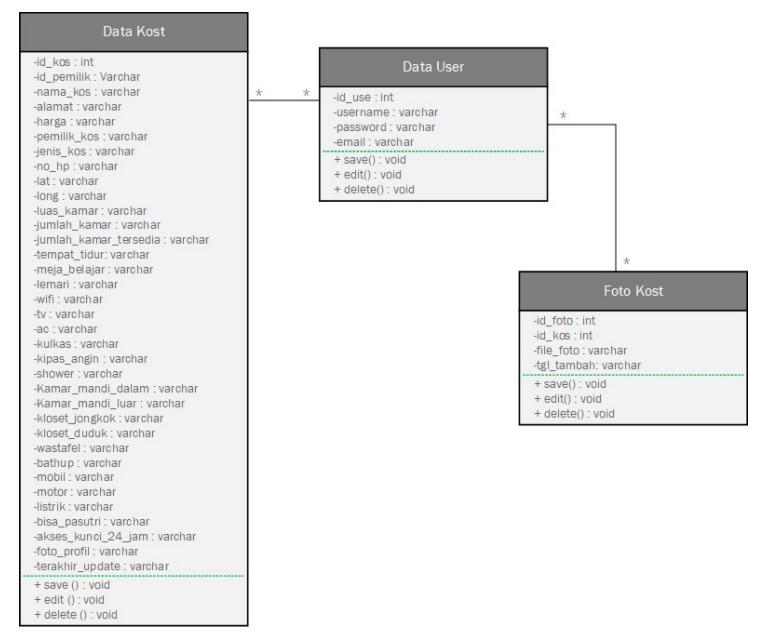

Fig. 3. Class Diagram.

In the design results of the class diagram, it has 3 entities, namely the user boarding data and the boarding details. The three entities have a relationship between the three. For designing the user interface as depicted in Figure 4 and Figure 5.

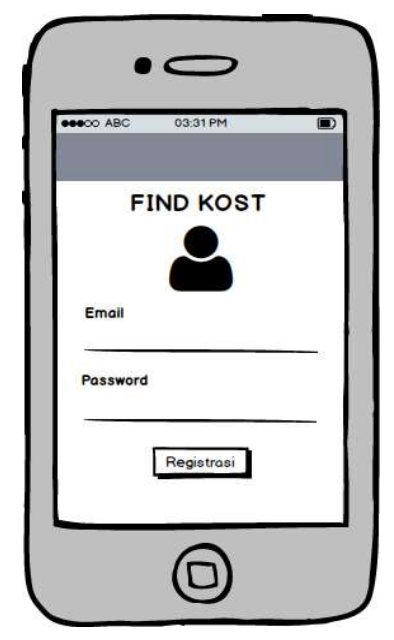

Fig. 4. User Interface Design.
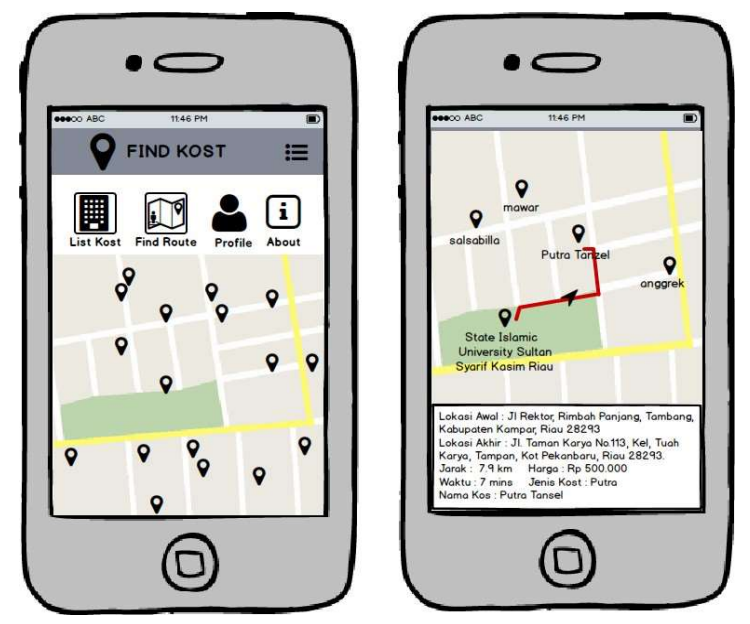

Fig. 5. User Interface Design. 


\subsection{Implementation}

At the implementation stage the author has implemented the results depicted in Figure 6 for the login page in Figure 7 and detail page in figure 8 .

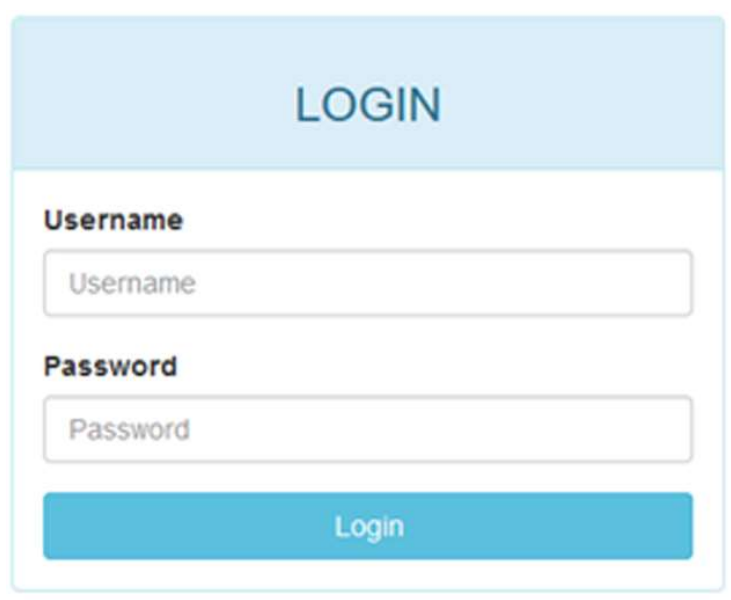

Fig. 6. Login Page.

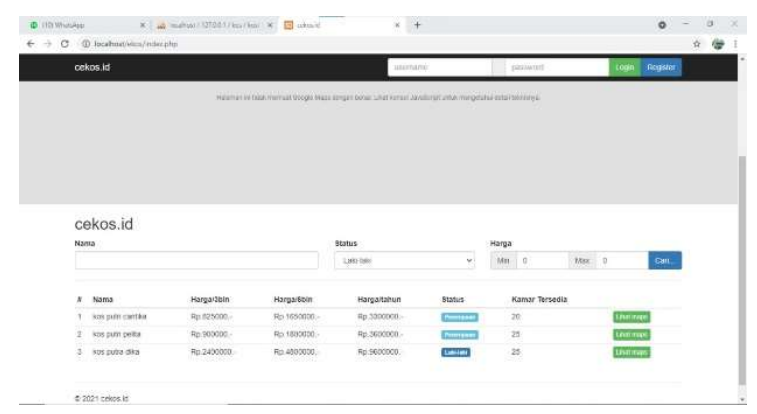

Fig. 7. Find Page.

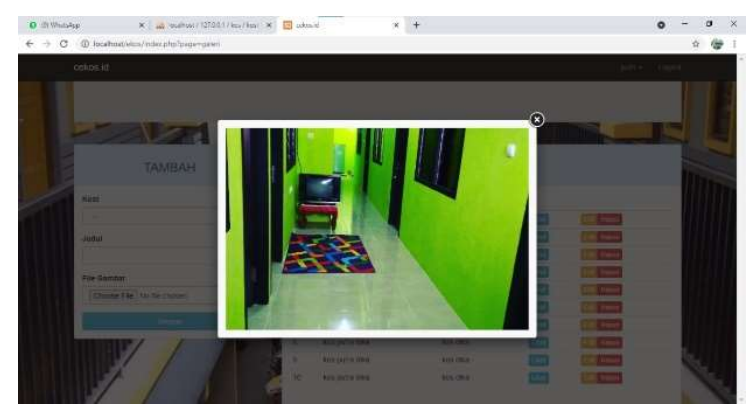

Fig. 8. Detail Page.

\subsection{Testing}

Testing is carried out with the help of the SortSite software tool to test the compatibility of the system that will be run later. In compatibility testing, SortSite divides 3 categories of problems (PowerMapper, 2019) namely critical issues, major issues and minor issues. From the compatibility test, the results are quite compatible because the system can run on various web browser platforms such as Firefox, chrome, opera mini. In this test, compatibility testing is used because the system must run on every web browser platform. The results obtained by the system can run on various web browser platforms as shown in Figure 9.

\begin{tabular}{|c|c|c|c|c|c|c|c|c|}
\hline Browser & IE & Edge & Firefox & Safari & Opera & Chrome & ios & Android \\
\hline Version & 11 & 92 & 90 & 14 & 77 & 92 & $\leq 13 \quad 14$ & 92 \\
\hline Critical Issues & () & () & (†) & ( ) & ( ) & ( ) & (-) () & ( ) \\
\hline Major Issues & $\theta$ & () & () & () & () & ( ) & (1) & () \\
\hline Minor Issues & (1) & () & (1) & (1) & ( ) & ( ) & & () \\
\hline
\end{tabular}

Fig. 9. Testing Result

\section{Conclusion.}

At this stage it can be concluded that there are 9 functional requirements with 3 actors in the system that has been built. At the design stage, the architectural design is obtained in the form of Use case diagrams and Business Process Modelling Notation (BPMN), data design that produces entity relationship diagrams (ERD), user interface design. After the design stage is the implementation stage, then the design that has been made is implemented. Then the implementation of the program code is based on component design that produces program code built with PHP and the Laravel framework. Then the last is the implementation of the interface which is made based on the design of the interface which is built with HTML, CSS and javascript. After that, compatibility testing was carried out with minor issues found in the IE, Firefox and Safari web browsers, but in this test sampled the opera, chrome and firefox web browsers, this test was considered valid.

\section{References}

[1] E. Bryndin, "Creative Communication Safe Ethical Artificial Intelligence in the Era of Technological Development," vol. 8, no. 3, pp. 13-23, (2020), doi: 10.11648/j.se.20200803.11.

[2] G. Aceto and V. Persico, "The role of Information and Communication Technologies in Healthcare: The role of Information and Communication Technologies in Healthcare: Taxonomies , Perspectives , and Challenges," no. February, (2018), doi: 10.1016/j.jnca.2018.02.008.

[3] H. Sepehrdoust and M. Ghorbanseresht, "Kasetsart Journal of Social Sciences Impact of information and communication technology and fi nancial development on economic growth of OPEC developing economies," vol. 40, pp. 546-551, (2019).

[4] D. Of, I. Technology, and O. N. Increasing, "DEVELOPMENT OF INFORMATION TECHNOLOGY TOWARDS INCREASING ONLINE BUSINESS," HIARKI Sci. J. Manag. Bus., vol. 2, no. 1, pp. 71-75, (2020).

[5] L. Ding, H. Wang, L. Ding, R. Guan, and Y. Xia, "Effects of advancing internet technology on Chinese employment: a spatial study of inter-industry spillovers Technological Forecasting \& Social Change E ff ects of advancing internet technology on Chinese employment: a spatial study of inter-industry 
spillovers," Technol. Forecast. Soc. Chang., vol. 161, no. November, p. 120259, (2020), doi: 10.1016/j.techfore.2020.120259.

[6] K. S. Sahoo, S. K. Mishra, S. Sahoo, and B. Sahoo, "Software Defined Network: The Next Generation Internet Technology," pp. 1-12.

[7] D. Suhartanto, P. N. Bandung, G. Leo, and P. N. Bandung, "Small business entrepreneur resistance of ICT adoption: a lesson from Indonesia Small business entrepreneur resistance of ICT adoption: a lesson from Indonesia Dwi Suhartanto and Gundur Leo *," no. January, (2018), doi: 10.1504/IJBG.2018.10015253.

[8] X. Zhao, "Analysis on the Construction of Entrepreneur Business Model under the " Internet Accelerated Speed 'Environment," vol. 6, pp. 1-8, (2019), doi: 10.4236/oalib.1105304.

[9] R. Priyaningrum and M. Wijaya, "International Journal of Multicultural and Multireligious Understanding Social Information Process on Instagram to Develop Social Entrepreneur Women in Madiun Indonesia," pp. 70-80, (2020).

[10] A. Rachmawati, "Building Boarding House Public Service Information Through WebBased Applications," vol. IX, no. 2, pp. 155162, (2017).

[11] P. Gede, S. Cipta, N. Wayan, and W. I. Wayan, "POINT OF SALE (POS) SOFTWARE INFORMATION SYSTEM WITH WEBBASED WATERFALL METHOD," vol. 10, no. 1, (2021).

[12] D. Model, J. Yu, I. Rutt, E. V Blagin, and V. V Biryuk, "Applying an MVC Framework for The System Development Life Cycle with Waterfall Model Extended," (2017), doi: 10.1088/17426596/755/1/011001.

[13] N. Hidayati, "Application of Waterfall Model In Development of Work Training Acceptance System," INTENSIF, vol. 4, no. 1, (2020)

[14] M. Nawang, L. Kurniawati, D. Duta, K. Akuntansi, S. Informasi, and K. Akuntansi, "DESIGN AND DEVELOPMENT OF DESCRIPTION-BASED INFORMATION SYSTEM INVENTORY DATA PROCESSING WITH MODEL," vol. 13, no. 2, pp. 233-238, (2017).

[15] Y. Firmansyah, "Application of SDLC Waterfall Method in Making Web-Based Academic Information System Case Study AlHabi Sholeh Islamic Boarding School, Kubu Raya Regency, West Kalimantan," vol. 4, no. 1, (2018).

[16] P. Sistem, I. Inventori, P. T. Pangan, and S. Sejahtera, "APPLICATION OF WATERFALL METHOD IN INVENTORY INFORMATION SYSTEM PT. HEALTHY FOOD," vol. 1, no. 2, pp. 30-40, (2017).

[17] H. Larasati, S. Masripah, and B. Tengah, "Analysis and design of the GRC purchasing information system with the waterfall method," vol. 13, no. 2, pp. 193-198, (2017).
[18] N. W. Cahyaningsih, D. S. Rusdiato, and K. C. Brata, "Application Development for Management and Monitoring of Official Travel (Case Study: SMK Canda Bhirawa Pare)," vol. 3, no. 12, pp. 10926-10932, (2019).

[19] R. P. Hirdad, B. Priyambadha, and D. S. Rusdianto, "Development of Management Application Submission of Case Study Lecturer Activities, Faculty of Administrative Sciences, Universitas Brawijaya," vol. 3, no. 6, pp. 52355241, (2019).

[20] T. K. Nasikhin, W. Hayuhardhika, N. Putra, and D. Pramono, "Analysis and Design of Tour and Travel Reservation Information System Using OOAD Method on Warok Tour and Travel," vol. 3, no. 11, pp. 10659-10666, (2019).

[21] A. Saepudin, R. Aryanti, E. Fitriani, and D. Ardiansyah, "E-Commerce System Design Using Rapid Application Development Model at Judo Karawang Branch Manager," vol. 23, no. 1, pp. 27-34, (2021).

[22] F. Teknik, S. Informasi, U. Batam, and K. Batam, "DESIGN AND CONSTRUCTION OF A WEB-BASED BOARDING HOUSE TO EASY LOOKING FOR KOST IN BATAM CITY," vol. 11, no. April, (2021).

[23] N. L. Hasanah, "WEB-BASED HOUSE MARKETING INFORMATION SYSTEM," vol. 8, no. 2, pp. 78-86, (2020).

[24] D. I. Ponorogo, D. F. Rosidin, I. P. Astuti, and A. Triyanto, "APPLICATION PROTOTYPE SEARCHING AND BOOKING BOARDING APPLICATION APPLICATION PROTOTYPE," vol. 1, no. 2, pp. 52-61, (2021).

[25] N. D. Putra, R. A. N. S. T, F. T. Elektro, and U. Telkom, "BACK-END DESIGN OF E-KOST APPLICATION WITH WATERFALL MODEL BASED ON WEB BACK-END DESIGN APPLICATION SOFTWARE OF EKOST WITH WATERFALL," vol. 7, no. 2, pp. 4814-4821, (2020). 